\title{
Robert Cieślak
}

\section{"wymienię wzrok na dotyk". Poetyka oglądu w twórczości Tadeusza Różewicza*}

\begin{abstract}
Cieślak Robert, „wymienię wzrok na dotyk”. Poetyka oglądu w twórczości Tadeusza Różewicza ["I will exchange sight for touch": The poetics of view in Tadeusz Różewicz's works]. „Przestrzenie Teorii" 21. Poznań 2014, Adam Mickiewicz University Press, pp. 23-38. ISBN 97883-232-2740-3. ISSN 1644-6763.

The author poses the question of the importance of a sensory experience in Tadeusz Różewicz's poetry, including the possibility of the co-existence of and/or replacement of the dominant sense of sight by that of touch. In poetic practice, this change is expressed by the metaphor "touching sight". Phenomenological analysis allows one to determine the cognitive order in which the perception of an image precedes the perception of a word. The author argues that the understanding of poetry as the philosophy of art requires establishing a list of recalls of images and reconstructing cognitive order (including the subjective experience of space), which together create the "poetics of view". When interpreted from this perspective, poetry can be treated as testimony to the knowledge of reality.
\end{abstract}

W ostatniej strofie Pragnienia, dedykowanego Pamięci Tadeusza Borowskiego, Tadeusz Różewicza pisał:

\author{
Chciałbym nie mówić \\ lecz czynić słowami \\ aby słów moich dotknęli rękami \\ ludzie
}

$$
\text { (P I 2571; podkr. - R.C.) }
$$

Gdyby ów fragment czytać w należnym kontekście historycznym (tom Wiersze i obrazy, z którego utwór pochodzi, zawierał teksty z lat 19511952), należałoby przyjąć, że mamy do czynienia z rodzajem poezji czynu,

* Artykuł jest zmienioną wersją referatu wygłoszonego na interdyscyplinarnej konferencji naukowej „Tadeusz Różewicz i obrazy” zorganizowanej przez Zakład Literatury i Kultury Nowoczesnej Instytutu Filologii Polskiej Uniwersytetu im. Adama Mickiewicza oraz Komisję Filologiczną Poznańskiego Towarzystwa Przyjaciół Nauk, która odbywała się 2-4 grudnia 2013 roku w Poznaniu.

${ }^{1}$ Cytowane fragmenty poezji Tadeusza Różewicza oznaczane będą bezpośrednio w tekście przy użyciu ujętych w nawias skrótów, w których literowo oznaczam tytuł książki, cyfrą rzymską stosowny tom, a cyfrą arabską numer strony. Skróty literowe odpowiadają następującym publikacjom: P - T. Różewicz, Poezje, Kraków 1988, t. 1-2; Pr/Uz - T. Różewicz, Proza, [w:] Utwory zebrane, t. 1-3, Wrocław 2004; zfr - T. Różewicz, zawsze fragment. recycling, Wrocław 1998. 
poetyckim wcieleniem woli mocy, awangardowym w genezie aktywizmem i formułowanym w jego duchu postulatem demokratyzacji twórczości artystycznej. Gdyby jednak przypomnieć strofę inicjalną wiersza:

Chciałbym dziś mówić tak barwnie i jasno

by dzieci biegły do mnie jak do parku

co w słońcu stoi i światło ma w sobie

(P I 257; podkr. - R.C.),

wówczas na plan pierwszy wysunie się problem barwy i światła, a cały utwór będziemy mogli uznać za „ars poetica”, z wszystkimi zastrzeżeniami, które wynikają z deklaratywnego charakteru wypowiedzi podmiotu, poszukującego wciąż odpowiedzi na pytanie „co to jest poezja?”. Dużo wcześniej, w Uczniu czarnoksiężnika, opublikowanym w tomie Niepokój, widzenie i mowa (rozumiana tu raczej jako język), ale także w równym stopniu słyszenie są źródłem dramatycznego obciążenia egzystencjalnego i historycznego zarazem, przez co stają się podstawą do wyrażenia samooskarżenia poetyckiego, aktem założycielskim innego bolesnego doświadczenia podmiotu, wynikającego $\mathrm{z}$ uświadomienia wyczerpania zarówno potencjału estetycznego, jak też etycznego:

Po co otwarłem oczy

Zalewa mnie świat kształtów i barw

[...]

Po co otwarłem uszy

napełniły mnie harmonie żywe

echa głosów umarłych

[...]

Po co rozwiązałem język

utraciłem milczenie złote

gaduła nie powiem nic nowego

pod słońcem.

(P I 27; podkr. - R.C.)

Nie sposób - zdaje się mówić podmiot wiersza Różewicza - w ramach dostępnego i skodyfikowanego systemu języka wyrazić poezję. Słowo nie jest reprezentacją obrazu, nie jest jego źródłem. Jako narzędzie dyskursów egzystencjalnych, historycznych, w swej genezie opresywnych, ustanawiających hierarchie i zależności, nie jest kodem adekwatnie reprezentującym rzecz-y-wistość, przez którą w tym kształcie rozumieć możemy ogół przedmiotowego świata przedstawiający się oku człowieka i przezeń postrzegany. 
Dlatego zapewne poetykę Różewicza z upływem lat dużo trafniej niż nadmiar słów określa dążenie do milczenia i zaniku obrazu poetyckiego jako konstrukcji czerpiącej wyłącznie z zasobów języka, a wielobarwna paleta obrazowania ustępuje konsekwentnie pola odcieniom szarości, rozpiętej i konkretyzującej się pomiędzy bielą a czernią. Jednak zakwestionowanie skuteczności postrzegania zmysłowego (opartego głównie, jak w powyżej przytoczonym fragmencie, na zmyśle wzorku i słuchu), choć poddane krytyce, opisane jako rodzaj doświadczenia traumatycznego, ostatecznie okaże się pozorne.

\section{Na początku był(o)...}

Na początku było słowo? Tak, ale - jak wiemy - słowo ujęte w ramę strategii negatywnej2, a także w ramę konwencji oraz zmiennych historycznie oraz ideowo znaczeń. W Poetyce (z tomu Wiersze i obrazy) Różewicz wprost diagnozuje stan rozpadu słów, „którym odjęto miłość” (P I 220), a działanie poety opisuje następująco:

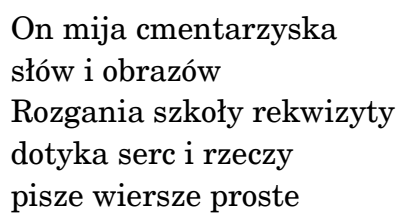

(P I 220)

Plan etyczny poetyki Różewicza, wywiedziony z genetycznie ekspresjonistycznego przesunięcia od estetyki ku etyce właśnie, pozwala przyjąć, że użyta tu metafora dotyku staje się ekwiwalentem nowej poezji, której istotą jest zmysłowy konkret. W ustanowionej przez poetę opozycji pomiędzy poezją piękna i konwencji a poezją dobra i nowego początku nie mamy jednak do czynienia z prostym wyparciem wzroku przez dotyk. Obrazy, o których tu mowa, przynależą bowiem wyłącznie do planu literackiego, a potrzeba ich dekompozycji została przez poetę gruntownie opisana między innymi w autorskim komentarzu Dźwięk i obraz w poezji wspótczesnej ${ }^{3}$. Tymczasem w miejscu zdekomponowanych słów i literac-

2 Zob. T. Kunz, Strategie negatywne $w$ poezji Tadeusza Różewicza. Od poetyki tekstu do poetyki lektury, Kraków 2005. Warto zauważyć, że autor tej pracy, komentując ustalenia Krzysztofa Kłosińskiego (Imię Róży, „Pamiętnik Literacki” 1999, z. 1, s. 10), dotyczące analizy dwukierunkowo skutecznego znaku, „który jednocześnie «dotyka serc i rzeczy»”, stwierdza: „Różewiczowskie «dotykać serc i rzeczy» należałoby więc odczytywać jako sprzeciw wobec tradycyjnie pojmowanej fikcjonalności (literackości)”. T. Kunz, Strategie negatywne w poezji Tadeusza Różewicza..., s. 89.

3 Zob. T. Różewicz, Przygotowanie do wieczoru autorskiego, Warszawa 1971, s. 97-100. 
kich skonwencjonalizowanych obrazów w poetyce Różewicza pojawia się nowa forma ekwiwalentyzowania widzenia i poznania wzrokowego. Wyłania się ona z zasady „przemyśliwania obrazów” (versus „obrazowania myśli”), pozwalającej niegdyś Bolesławowi Leśmianowi dookreślić warunki poznania poetyckiego opartego na dyspozycjach percepcyjnych człowieka pierwotnego ${ }^{4}$, konkretyzuje w porządku dookreślonym formułą „oka poety”5 i realizuje w epoce kryzysu tradycyjnej władzy wzroku ${ }^{6}$.

Problem znaczenia i miejsca obrazów w twórczości Różewicza wymaga spojrzenia z perspektywy wielu dyscyplin, oczekuje elementarnej syntezy, która być może pozwoli:

1) przypomnieć zainteresowania poety obrazem malarskim (szerzej sztukami wizualnymi),

2) zrekapitulować zasady prowadzenia dialogu międzytekstowego,

3) zrekonstruować zasadnicze elementy teorii obrazu poetyckiego,

4) opisać praktykę widzenia oraz skutki artystyczne przesunięcia zainteresowania z obrazu malarskiego na ikonosferę współczesności,

5) wyodrębnić podstawowe cechy poetyki oglądu, stanowiącej podstawę do postawienia tezy, że $\mathrm{w}$ istocie $\mathrm{w}$ tym przypadku poezja jest poznaniem,

6) podjąć próbę odpowiedzi na pytanie, czy deklaracja „wymiany wzroku na dotyk" jest w opisanych warunkach poetyki możliwa do realizacji.

\section{O potrzebie i pułapkach inwentaryzacji}

Badanie związków literatury i malarstwa w początkowej fazie, pozwalającej na rozpoznanie potencjału analitycznego danego korpusu tekstów, przypomina inwentaryzację jako jedną ze starszych metod stosowanych przez historię sztuki. W odniesieniu do twórczości autora Opowiadania dydaktycznego syntetyczna kartoteka odniesień plastycznych, źródeł inspiracji wizualnych, bezpośrednich oraz implikowanych nawiązań obrazowych obejmuje różnorodne style, gatunki i zbiory malarstwa, rzeźby, architektury, filmu, telewizji oraz obserwacji ikonosfery współczesnego miasta. W konsekwencji zmuszona jest między innymi do odnotowywania wielu miejsc, w których udostępniane są dzieła sztuki.

${ }^{4}$ Zob. B. Leśmian, Znaczenie pośrednictwa $w$ metafizyce życia zbiorowego, [w:] tenże, Szkice literackie, oprac. J. Trznadel, Warszawa 1959, s. 47.

${ }_{5}^{5}$ Zob. R. Cieślak, „Oko poety”. Poezja Tadeusz Różewicza wobec sztuk wizualnych, Gdańsk 1999.

${ }^{6}$ Zob. tenże, Widzenie Różewicza, Warszawa 2013. W niniejszej pracy korzystam z kilku ustaleń, które znalazły swoje obszerniejsze realizacje na kartach tej książki. 
Inwentaryzowanie wymaga podjęcia podróży (powtórzenia drogi ciała i oczu) wprost ku zabytkom architektury, kompletnym zbiorom i poszczególnym artefaktom gromadzonym w Krakowie, Wenecji, Rzymie, Florencji, Neapolu, Sienie, Paryżu, Colmarze, Monachium, Wiedniu, Antwerpii, Rotterdamie, Brukseli, Londynie, Nowym Jorku, Zurychu..., a i tak $\mathrm{w}$ ten sposób wymienione - będą to tylko miejsca wskazywane przez poetę bezpośrednio. Wydaje się, że nie do pominięcia byłoby również osobiste doznanie przywoływanych w Et in Arcadia ego kontrastów między ciszą Capodimonte a zgiełkiem placu przed Stazione Centrale Napoli, odczucie zmęczenia upałem Południa, ogarnięcie wzrokiem majestatycznej wielkości term Karakalli, wsunięcie dłoni w szczelinę Bocca della Verità. Wszystko po to, aby nie biec przez Palazzo Ducale, jak w Za przewodnikiem, nie ekscytować się wraz ze współzwiedzającymi prezentowanym w tamtejszej zbrojowni pasem cnoty, lecz „zamieszkać we wnętrzu obrazu", zatrzymać się na dłużej niż trzy sekundy przed Fornarina Rafaela Santiego w Palazzo Barberini, obserwując w tym samym czasie zachowania innych oglądających i pilnujących jednocześnie (podobnie jak w cyklu $Z$ muzeum notatki, kiedy te same procedury odnieść należy do krakowskich Sukiennic i obrazu Władysława Podkowińskiego Szał uniesień), wracać w te same miejsca kilkakrotnie, powtarzać doświadczenie wzrokowe (w tym somatyczne doświadczenie przestrzeni), uczyć się patrzenia na malowidło, ale też myślenia o jego „treści”, o jego istocie.

Wiersze i poematy Różewicza bez trudu w ten sposób doprowadzą podróżnika do obrazów Francisa Bacona i Josepha Mallorda Williama Turnera w Tate Gallery, fresków Jacopo Tintoretta w Scuola Grande di San Rocco oraz zbiorów sztuki dawnej w Gallerie dell'Accademia, aby już po chwili skierować uwagę wędrowca ku kolekcji sztuki nowoczesnej Peggy Guggenheim w Wenecji (a więc do rzeźb Alberta Giacomettiego oraz stworzonych techniką drippingu obrazów Jacksona Pollocka, a także płócien, które namalowali: Giacomo Balla, Umberto Bocconi lub Carlo Carrà), choć być może także do paleolitycznej Wenus z rogiem (znanej jako Wenus z Laussel) z Musée d'Aquitaine w Bordeaux. Postawią również czytelnika-inwentaryzatora przed bizantyjskimi mozaikami („pięknym piekłem" wspominanym w Et in Arcadia ego) w katedrze Santa Maria Assunta na Torcello i przed obrazami Emilia Vedovy czy rzeźbami Roberta Lardery w Ca' Pesaro (Galleria Internazionale d'Arte Moderna) nad Canale Grande. Pozwolą odnotować co najmniej kilka wybranych dzieł z Bazyliki św. Piotra i zbiorów Muzeów Watykańskich (tu Pietà oraz freski w Kaplicy Sykstyńskiej Michelangela Buonarrotiego oraz Bitwa pod Wiedniem Jana Matejki), jednocześnie kierując kroki wędrowca do rzymskiej Galleria Nazionale d'Arte Moderna, między innymi przed pra- 
ce Alberta Burriego, które Różewicz oglądał jednak w pawilonie włoskim weneckiego Biennale, a opisał potem w Opowiadaniu dydaktycznym, dedykowanym historykowi i krytykowi sztuki, przyjacielowi jeszcze z okresu krakowskich studiów, Mieczysławowi Porębskiemu. W ten więc sposób utwory poety odsłonią także specyfikę ekspozycji weneckiego biennale, zachęcą do treningu oka $\mathrm{w}$ postrzeganiu symultanicznie rejestrowanego dynamizmu futurystów, deszyfrowania eksperymentu wizualnego ustanowionego w wielooglądowości malarstwa kubistycznego, ale jednocześnie (w pełni palimpsestowo) przemyśliwania olśniewających żółcieni Zmartwychwstania z Oltarza z Isenheim. Skłonia do refleksji nad techniką ekspresjonistów monachijskich i wiedeńskich, jak również nad fenomenem światła w martwych naturach Pietera Claesza, a także do namysłu nad ekspresją wzroku modeli z obrazów Fransa Halsa, czy wreszcie technikami malowania ciała Chrystusa we wszystkich wersjach Rubensowskiego zdjęcia z krzyża, z tryptykiem przechowywanym w katedrze Najświętszej Marii Panny w Antwerpii na czele. Pozwolą z większą świadomością wczytywać się w obrazy Tadeusza Makowskiego, Witolda Wojtkiewicza, Andrzeja Wróblewskiego, Jerzego Nowosielskiego i wielu innych. Oto zaledwie zarys drogi, której przebycie jest niezbędne, aby zrekonstruować podstawy podmiotowego imaginarium, aktem założycielskim którego jest zakres metatekstualnie wskazywanych, ale także implikowanych zainteresowań wizualnych poety.

$\mathrm{Na}$ marginesie warto zauważyć, że choć bez wątpienia pozycję znaczącą w kompozycji tegoż imaginarium zajmuje sztuka niefiguratywna, rezygnująca programowo $\mathrm{z}$ perspektywizmu renesansowego, tworząca zręby nowoczesności w obszarze reprezentacji widzenia chociażby poprzez rozszczepienie rysunku i koloru, symultaniczny dynamizm czy eksperyment dadaistyczny, to jednak dotychczasowy ton wypowiedzi krytycznych ustanawiany jest przez odmiennie rozłożone punkty ciężkości. Lektura literatury przedmiotu sprzyja bowiem powstaniu obrazu twórczości poetyckiej, w której głównymi punktami odniesień dla interpretacji dzieła Różewicza są: malarstwo Francisa Bacona (pośrednio przez tę twórczość jedynie zapośredniczone dzieło Diega Velázqueza), a potem przede wszystkim spuścizna Starych Mistrzów: Hieronima Boscha, Matthiasa Grünewalda, Rembrandta, Pietera Bruegla, Fransa Halsa i innych. Refleksja literaturoznawcza komponuje swoją własną hierarchię, nie dostrzegając wyraziście, że Tadeusz Różewicz podgląda dawne malarstwo $\mathrm{z}$ perspektywy zmiany kulturowej, jakiej $\mathrm{w} \mathrm{XX}$ wieku dokonał ruch awangardowy. Tradycja i dziedzictwo są niepomijalne, ale znaczące jest spojrzenie na nie okiem nowoczesności oraz towarzyszące takiemu spojrzeniu nowe myślenie o nowym człowieku w nowym - jakże odmiennym - 
czasie. Dlatego tak istotne wydaje się rekonstruowanie imaginarium Różewicza jako również, a może przede wszystkim zbioru pozaliterackiego, fundującego w tym kształcie narzędzia rekonstrukcji poetyki oglądu. Innymi słowy, inwentaryzacja metatekstualnych wykładników wskazujących na inspiracje z obszaru sztuki jest niewystarczająca dla rozpoznania kompetencji wizualnych poety. Dla pełnego zrozumienia związków poezji i malarstwa niezbędne jest zarówno zrekonstruowanie możliwie kompletnej mapy różnorodnych spostrzeżeń, jak też próba ustalenia dynamiki poznania wzrokowego podmiotu, dookreślonej przez porządek pojęć: obraz (malarski) - słowo - znaczenie - słowo (poetyckie) - obraz (poetycki).

Tak rozpoczyna się również śledzenie ikonosfery oraz obrazów multiplikowanych przez kulturę masową jako miejsc, w których intensywna aktywność wizualna człowieka stanowi coraz wyrazistszy dowód upośledzenia jego zdolności kreacyjnych, ale też w tym samym momencie i na tej samej drodze dokonującego się ograniczenia władz poznawczych w porządku ustanowionym jeszcze przez Platona.

„Różewicz wizualny” to twórca kolaży tekstowych oraz obrazowych palimpsestów poetyckich, w których liczne fragmenty dziejów sztuki pod postacią idei, wybranych motywów ikonograficznych lub powtórzonych zasad konstrukcyjnych (wzorców gatunkowych) wychylają się ku widzowi/czytelnikowi w miejscach swoistych „przetarć kulturowych”, wydobywających się spod warstw nowszej myśli artystycznej, programowych założeń awangard czy świadectw przygodnych obserwacji paradoksów sztuki współczesnej.

Choć być może zabrzmi to paradoksalnie, przyznać należy, że Poeta nie jest stałym praktykiem ekfrazy. Niezmiernie rzadko opisuje szczegółowo i wprost doznania wzrokowe. W ten sposób ucieka przed manierą „malowania słowem”. Przywołuje raczej warstwę malarską, by mieć pretekst do interpretacji i krytycznego komentarza. Lekceważy szczegóły pojedynczego przedstawienia obrazowego, za ważniejsze uznając słowne ekwiwalentyzowanie uogólnionych założeń ideowych dzieła, a niekiedy syntezy całego, twórczego dorobku danego artysty. Na gruzach myśli historycznej, odrzucając dotychczasowe pojmowanie piękna, a także rozumienie obrazu poetyckiego jako metaforycznego „ozdobnika”, wyciągając wnioski z lekcji ekspresjonizmu, rekonstruuje estetykę, dla której przedmiotem dociekań jest metoda wyrażania się człowieka poprzez sztukę. $\mathrm{W}$ ten sposób - jak się wydaje - estetyka budowana na podstawie namiastkowego, pretekstowego, polemicznego lub wirtuozowskiego przywołania dzieł sztuki wizualnej staje się swoistym projektem pozytywnym poetyki Różewicza, otwierającym drogę do ocalenia tożsamości człowieka współczesnego. Wiersz, który przybiera kształt dysputy o sztuce, jest 
jeszcze czymś ponadto - staje się figurą epistemologiczną. Rejestracja aktu podmiotowej percepcji, swoistych ćwiczeń oka poetyckiego rozpoczyna się w relacji pomiędzy literaturą a malarstwem. Uważne oko czytelnika szybko jednak dostrzeże rozproszone w całym dziele świadectwa bardzo indywidualnego postrzegania świata.

\section{Obraz przed słowem?}

Czymś oczywistym byłoby stwierdzenie, że poeta wraz z kolejnymi tomami wierszy zarówno wzbogaca - jak to sam określa - „skrzynkę technika-mechanika" w patrzeniu na dzieła sztuki, doskonaląc umiejętności percepcyjne, jak też dąży do konstruowania wypowiedzi maksymalnie oszczędnej w słowie - znaku danych świadomościowych. Oba doświadczenia - obrazowe (postrzeżeniowe) i językowe (literackie, kreacyjne) wynikają wszak z przyjęcia określonej postawy poznawczej. Zabieg oszczędności w oznaczaniu słowem tego, co widziane, przy jednoczesnym tworzeniu niemal nieograniczonego, choć skupionego wokół konkretnego przedmiotu pola obserwacji, przypomina - co nietrudno wszak zauważyć - procedurę redukcji fenomenologicznej. Jest więc w swej istocie zarówno próbą rekonstrukcji kolejnych aktów spostrzeżeniowych w ich postaci nieobciążonej dyskursem/mową potoczną, jak też objawia intencję wykraczania/wychylenia w stronę wizualnych konkretyzacji dostępnych czytelnikowi, uprzednio wpisanych potencjalnie w tekst poetycki. Nowy język Różewicza jest źródłem, z którego rodzi się poezja filozoficzna w odmianie - jak proponuje to Edward Balcerzan - nie traktatu czy ilustracji idei, lecz „filozofii ukrytej w poezji”.

W tej właśnie sytuacji obraz poetycki jako formalny ozdobnik, jako wytwór „wymyślonej wyobraźni” (dodajmy: wymyślonej, czyli czysto językowej), niezależnie od tego, jak wielkiego kunsztu twórczego jest on świadectwem, zostaje w tej poetyce zniesiony. Krytyka tak pojętego obrazu jest gestem odrzucenia programowych założeń awangardy oraz wyraźną deklaracją artystyczną (sprzeciw wobec zewnętrznego, szczególnie podejrzanego w drugiej połowie XX stulecia piękna), ale jest też projektem własnej poezji, która nadal powinna istnieć jako sposób wyrażania rozumiany w duchu teorii ekspresjonizmu.

W Kartkach wydartych $z$ „dziennika gliwickiego" pod datą 13 sierpnia 1955 roku niezwykle krytycznie oceniając swój tom Wiersze i obrazy, poeta próbował zaprezentować sposób rozumienia nowego typu obrazu:

${ }^{7}$ Zob. E. Balcerzan, Poezja polska w latach 1918-1939, Warszawa 1996. 
Kiedy czytam swoje wiersze, czasem już coś przez nie widzę - jakiś jeden obraz (nie o „obrazy” tu chodzi!), coś się przebija, ale za chwilę znów muł; nic nie wiem. [...] Pewne obrazy nie łączą się, ale zderzają. Nie budowanie, ale rozbijanie. Obraz wpada na obraz, odrzucone od siebie zderzają się z innymi obrazami.

(Pr/Uz III 322)

Możliwość ujrzenia obrazu wyłaniającego się zza słów, konkretyzowanego nie w systemie gramatycznej i frazeologicznej harmonii, lecz $\mathrm{w}$ toku zderzeń kolejnych przedstawień jako fenomenów powstających w wyniku redukcji ejdetycznej - to proces, który nie należy do dziedziny psychologii tworzenia, lecz do porządku epistemologicznego.

\section{Poezja jako poznanie}

Sposobu wyrażania świata u Różewicza szukać więc należy w nieustannej oscylacji pomiędzy założeniami właściwymi zwolennikom uprzedniości sensu (logosu predyskursywnego) wobec logosu pojęciowego a poglądami wywiedzionymi z tezy o dominującej w procesie poznania pozycji gramatyki (uprzedniości zdania wobec obrazu). Prościej można to wyrazić pytaniem: co jest pierwsze - doznanie wzrokowe (następnie obraz) czy gotowa nazwa (pojęcie) narzucająca widzenie? Pomocna w odpowiedzi okazuje się Różewiczowska metafora „oka poety”, która w szerokim rozumieniu wskazuje na dominująca pozycję wzrokowych danych percepcyjnych w procesie twórczym, w węższym ujęciu natomiast określa taki typ doświadczenia sensu, dla którego widzenie nie jest tak, jak chce tego tradycja metafizyczna, przedmiotem myślenia, lecz mając charakter intencjonalny wraz $\mathrm{z}$ cechującym je otwarciem ku światu zostaje uwolnione od myślenia pojęciowego, staje się „myśleniem widzenia”. Zgodnie z poglądami postfenomenologii, które omawia Iwona Lorenc, przez tak pojęte doświadczenie sensu danego $\mathrm{w}$ widzeniu rozumie się logos przysługujący widzeniu .

Twórczość wierna „oku poety” wypełnia więc ten z postulatów Merleau-Ponty'ego, w którym sztuka poprzez doświadczenie estetyczne otwiera drogę do poznania tego, co źródłowe, co jest istotą „logosu estetycznego”, a czego poznanie możliwe jest poza porządkiem dyskursu pojęciowego. Przedmiotem literaturoznawstwa może być zatem ustalenie, czy obraz powstaje w wyniku dyskursywnego myślenia narzucającego formy, a przez nie sensy rzeczom widzianym, czy też możliwe będzie widzenie bez zasłon (ekranów) języka pomiędzy podmiotem a widzianą rzeczą.

8 Zob. I. Lorenc, Świadomość $i$ obraz. Studia z filozofii przedstawienia, Warszawa 2001. 
Widzenie Różewicza, tak jak i widzenie w jego poezji, ma swoją gramatykę. To gramatyka myślenia „okiem poety”, domagająca się wciąż nieustannej rekonstrukcji językowej.

Zaledwie zarysowałem poszczególne etapy dochodzenia do zrozumienia intencji tekstu, ale droga wydaje się wyrazista. Inspirowane poezją powtórzenie doświadczenia wzrokowego i budowanie imaginarium były i są niezbędnym ćwiczeniem percepcji, a także swoistą praktyką podmiotowej pamięci. W ślad za patrzeniem oraz odczuciem przestrzeni ( $\mathrm{w}$ duchu i zgodnie $\mathrm{z}$ zasadą rekorporalizacji podmiotu myślącego jako jednej z cech kryzysu tradycyjnej władzy wzroku) pojawiają się pytania stawiane wierszom: o cel i sens przywołań obrazowych, o sposób przekształcania przedstawienia malarskiego (szerzej także świadomości wzrokowej) w słowo, o tryb ujawniania poglądów epistemologicznych, o istotę relacji poezji i filozofii. Poznawanie dzieła i poety tą drogą ujawnia wyjątkowość konsekwentnej i wszechstronnej koncepcji oscylacji języka i obrazu - propozycji uważnego poszukiwania słowa, pozwalającego uchwycić nienazwane, ledwie uchwycone przez świadomość doznania, jakich dostarcza najszlachetniejszy ze zmysłów człowieka - wzrok.

Propozycja taka pozwala na poszerzenie pola badawczego na każdy, nie tylko malarski, nie tylko plastyczny czy filmowy obraz przedstawiający się oku poety.

\section{Teoria widzenia}

Rekonstruowana w zaproponowanym porządku teoria widzenia Tadeusza Różewicza zasięgiem swym objąć musi każde podmiotowe doznanie wzrokowe. Rozbudowana ikonosfera współczesności nie wyczerpuje swojego potencjału w dziełach sztuki malarskiej, czy szerzej plastycznej. Objąć musi również teksty kultury wizualnej przynależne sztuce filmowej, ale też telewizji czy przestrzeniom wizualnym miast. W przypadku tych pierwszych rozpoznać można uzupełnienie poetyki Różewicza o technikę montażu filmowego, ale też o poetycką rekonstrukcję założeń ideowych nowego realizmu, ukonstytuowanego w powojennym kinie włoskim. Telewizja natomiast i jej „obrazy”, współwystępując z doniesieniami prasowymi (w tym tytuły artykułów i hasła reklamowe zaczerpnięte $\mathrm{z}$ ogłoszeń), stają się u Różewicza źródłem tematu, ale także przedmiotem opisu lub wzorcem strukturalnym tekstu literackiego. Oto bowiem Motyle rozpoczynają się relacją z prezentującego skutki powodzi we Florencji telewizyjnego reportażu, który na zasadzie asocjacji uruchamia potok dalszych wątków wspomnieniowych. Collage'owe zestawienia opisów filmów dokumentalnych z przytoczeniami części programów obejrzanych na 
szklanym ekranie, zasłyszanych $\mathrm{w}$ radiu lub przeczytanych $\mathrm{w}$ doniesieniach prasowych, wypełniają poemat Spadanie. Tytuły artykułów i nagłówki reklam to „przedmioty gotowe” w Non-stop-shows, gdzie uzasadnieniem tezy przekonującej, że świat jest dziedziną „gry z możliwościami”, zdaje się fragment: „Więc czyta się gazetę książkę” (P II 217).

"Czytanie" takie już po chwili otwiera dostęp do ikonosfery obszarów miejskich: „coraz częściej czyta się na murach/naszych miast [...]” (zfr, 100). Recycling w całości stanowi Różewiczowską próbę rejestracji i autorskiego porządkowania „szumu medialnego”. Zgodnie z własną ramą interpretacyjną (sposobem rozumienia świata) poeta wybiera $\mathrm{z}$ potoku doniesień zaledwie kilka sztandarowych tematów, zestawiając w jednym utworze "gorącą" medialnie w chwili pisania wiersza problematykę gromadzonego w skarbcach szwajcarskich banków złota i depozytów pieniężnych osób pochodzenia żydowskiego, które poniosły śmierć w wyniku polityki eksterminacyjnej Niemiec nazistowskich w latach II wojny światowej z równie „gorącymi” informacjami o zagrożeniu zachorowaniami na chorobę Creutzfeldta-Jakoba, czyli tak zwaną chorobę szalonych krów oraz wszelkimi pochodnymi tychże hiobowych wieści o BSE. Jednocześnie poeta wydobywa z procesu komunikowania masowego te momenty, które sprzyjają tworzeniu wizji „śmiertelnego tańca”, skazującego człowieka w kontakcie ze światem na ograniczenie poprzez pośrednictwo medialne ze swej natury pełne sprzeczności, niekonsekwencji oraz uproszczeń i selekcji faktograficznych. Poeta rejestruje kilka znaczących przykładów, w których poświadcza, jak wiele informacji pozostaje w świadomości czytelnika gazet lub widza telewizyjnego. Zauważa na przykład fragment relacji o wynikach kontroli w zakładach mięsnych, w której unijni kontrolerzy stwierdzają: " "no comment» powiedzieli do dziennikarzy” (zfr, 113) albo sam dopisuje ironiczny komentarz do wiadomości o eksperymentach genetycznych na bydle, zapisując określenie rodzaju środka przekazu wielką literą: „krowy w Telewizji śmieją się” (zfr, 115).

O istotnym dla poetyki tekstu literackiego znaczeniu obrazu świata, jaki staje się składnikiem świadomości podmiotu, konstruowanej w wyniku obserwacji strumienia wizualnego emitowanego na ekranie telewizyjnym, świadczy także fragment Strawionego. Określenie tożsamości podmiotu, będącego porte parole Autora, przyjeżdżającego do Nowego Jorku na premierę Białego małżeństwa, odbywa się właśnie poprzez obserwację obrazów telewizyjnych:

[...] chłopak pokazuje mi, gdzie stoi telewizor - co nacisnąć - co włączyć. 20 lub 23 „kanały”... najlepszy program na 9 lub $13 .$. do widzenia wieczorem, po przedstawieniu... Zostaję sam... Odjechali. Siadam („szczęśliwy”) przed telewizorem. Kanał 3, kanał 4, kanał 5, kanał 13, 20... co parę sekund przekręcam gałkę... ob- 
razy gonią obrazy muzyka muzykę słowa słowa... zatrzymuję się chwilę na jednym z programów... ale znów ulegam „małpim” pokusom i kręcę... karuzela obrazów i dźwięków. Obraz zresztą niezbyt wyraźny... przyprószony jakby śniegiem... no dobrze... jestem okazem współczesnego człowieka... nie chciałem znaleźć się w „środku życia” wśród żywych ludzi z krwi i kości... którzy na mnie czekali... ale z wielką zachłannością pożeram cienie, które żyją „w magicznej skrzyni”... (po kilku dniach skręciłem sobie boleśnie nogę i spędzałem przed małym ekranem jeszcze więcej czasu... nie mogłem chodzić... siedziałem po kilka godzin przed telewizorem... no tak, mogę powiedzieć, że poznałem trochę programy TV amerykańskiej...) ciągle jeszcze kręciłem gałką, ale już potrafiłem obejrzeć np. cały film. Wszystko gdzieś biegło: filmy reklamy makaronu nart kremów lakierów jakieś cudowne kobiety śpiewały ulatując w niebo (to właśnie one miały czekać na mnie w „Ameryce”...) potem gry liczbowe, wiadomości ze świata... właściwie nie czułem potrzeby, żeby coś obejrzeć do „końca”... nic się nie kończyło od rana do rana... wszystko wychodziło wchodziło w siebie... i znów uśmiechy i jakieś wojsko... dyplomaci... Szekspir... odkurzacze... i śmiech... śmiech... uśmiechy cudowne uśmiechy niezwykle białe sztuczne rekiny... nie czułem potrzeby, żeby policjant złapał mordercę, kochanek posiadł kochankę... przerywa pocałunek i chwali makaron mydło pastę do zębów... zrozumiałem, co pożera świat realny... że nic się z niczym nie łączy albo wszystko z wszystkim, a potem można popełnić samobójstwo zapić się na śmierć zamordować kogoś bez powodu zostać męczennikiem katem; nikt nie wytrzyma takiej pigułki, jaką jest telewizja... zjadłem banana, wyjrzałem przez okno rzuciłem okiem na obrazy na grzbiety książek... przymykałem oczy... zjadłem mandarynkę... jaki to smak? Ten sam smak tu w grudniu 1975 roku... i w Chinach jesienią roku 1958... opisywanie smaku... pisarz zamknięty odcięty odizolowany korkiem osiągnął mistrzostwo opisując smak ciasteczka... no dobrze... to prawdziwy realizm... i co zrobić z takim niezwykłym darem... zjadłem mandarynkę... przyjechali z teatru.

(Pr/Uz II 272, 273)

\section{Poetyka oglądu}

W przyjętej tutaj perspektywie dominującym pośród dostarczających doświadczeń zmysłowych jest zmysł wzroku. Jednocześnie, należy to zaznaczyć raz jeszcze wyraźnie, ocena charakteru tejże dominacji musi uwzględniać wszystkie konsekwencje, wynikające z faktu osłabienia zdolności widzenia w XX stuleciu. Literatura przedmiotu określa to zjawisko terminem „kryzysu tradycyjnej władzy wzroku” lub „kryzysu wzrokocentryzmu”. Epoka kryzysu stawia nas twarzą w twarz z fundamentalnym

9 Zob. M. Jay, Kryzys tradycyjnej władzy wzroku. Od impresjonistów do Bergsona, przeł. J. Przeźmiński, [w:] Odkrywanie modernizmu. Przekłady i komentarze, red. R. Nycz, Kraków 1998, s. 318. Więcej na temat skutków osłabienia tradycyjnych władz poznawczych, ufundowanych przez zmysł wzroku w odniesieniu do polskiej poezji minionego stu- 
paradoksem. Polega on na niewspółmierności osobistego doświadczenia wzrokowego podmiotu (człowieka współczesnego) wobec skuteczności (sprawdzalności) procesów poznawczych, wynikających z dostarczanych przez zmysł wzorku spostrzeżeń. Inaczej mówiąc - niepoliczalność spostrzeżeń, która stała się cechą dzisiejszej kultury wizualnej (wspomagany rozwojem technologii przyrost liczby postrzeganych obrazów, atakujących wzrok w przestrzeni publicznej), nie wpływa na wzrost pewności w orzekaniu o rzeczywistości. W dużym uproszczeniu rzecz ujmując, można powiedzieć, że świadomość tego, co dla zmysłów rzeczywiste (wyodrębnienie przedmiotu oglądu, sensualne uchwycenie obrazu) nie jest równa poznaniu rzeczywistości. Interpretacja świata rodzi się więc z przeogromnej liczby spostrzeżeń, lecz już nie z istotnego poznania (zrozumienia) tego, co postrzeżone. Zalew obrazowości w kulturze (w ikonosferze) osłabia zdolność widzenia. Opisanie świata w perspektywie okulocentrycznej w coraz mniejszym stopniu pozwala ten świat zrozumieć.

Wydaje się zatem, że próba odpowiedzi na pytanie o sposób prezentowania doświadczenia wzrokowego (jako zespołu zmysłowych danych postrzeżeniowych) we współczesnym tekście literackim powinna lokować się na przecięciu kilku równoległych, przeprowadzanych palimpsestowo analiz. Językowe wykładniki oglądowości są bowiem rodzajem reprezentacji danych zmysłowych. W istocie jest tak, że to one dopiero są dostępnym nam świadectwem podmiotowego poznania, konkretyzacją obrazu uchwyconego intelektualnie na scenie świadomości transcendentalnej ${ }^{10}$. Świadectwo takie nie jest więc niczym innym, jak dowodem na to, że poezja powstająca - co oczywiste - w wyniku złożonych procesów poznawczych podmiotu jest także sposobem wyrażania wyników tychże procesów i w tym rozumieniu jest poznaniem.

W rozmowie o poetyce oglądu będzie więc chodziło ostatecznie o takie rozpoznanie świata poetyckiego, dla którego doświadczenie wzrokowe jest punktem wyjścia do tworzywa językowego, gdzie wreszcie doznania zmysłowe stanowią początek i podstawę pracy wyobraźni, „matecznik lirycznej wrażliwości”. Oglądowość tekstu literackiego będzie więc wypadkową językowo wyrażonych, wcześniej postrzeżonych obrazów oraz podobnie konkretyzowanych przestrzeni, będzie także efektem zdolności tworzenia własnego imaginarium, komponowanego w podróży, stanowiącej podstawę naocznego doświadczania świata. Podejmowana w tym kontekście próba odnajdywania znaczeń poetyckich musi uwzględniać różnorodne przecięcia (inwencje geometryczne jako reprezentacje rysunku, występu-

lecia zob. R. Cieślak, Poezja wobec kryzysu władzy wzroku. Studia o słowie, obrazie i percepcji, Szczecin 2006.

${ }_{10}$ Uwagi na temat fenomenologicznego procesu postrzegania zob. I. Lorenc, Świadomość i obraz..., s. 83-140. 
jące na przykład w funkcji wizualnego tematu ramowego) oraz wszelkiego typu metaforyczne palimpsesty barw i sensów, które łącznie dadzą początek procesowi interpretacji poezji oraz wyznaczą ramy i kształty poetyki oglądu.

\section{Appendix (dopisany przez...)}

Rozpoczynająca tytuł artykułu fraza pochodzi $\mathrm{z}$ wiersza drobne ogłoszenia $i$ wróżby (P/UZ IV, 374-375). Sygnał taki uwagę interpretatora skierować powinien po raz kolejny ku analizie zawartości mediów. $\mathrm{W}$ istocie bowiem chodzi o szum informacyjny oraz nieograniczoność wariantywnej analizy transakcyjnej prowadzonej w porządku ustanawianym przez spektakularność konsumpcji. Przywołajmy ów wiersz w całości:

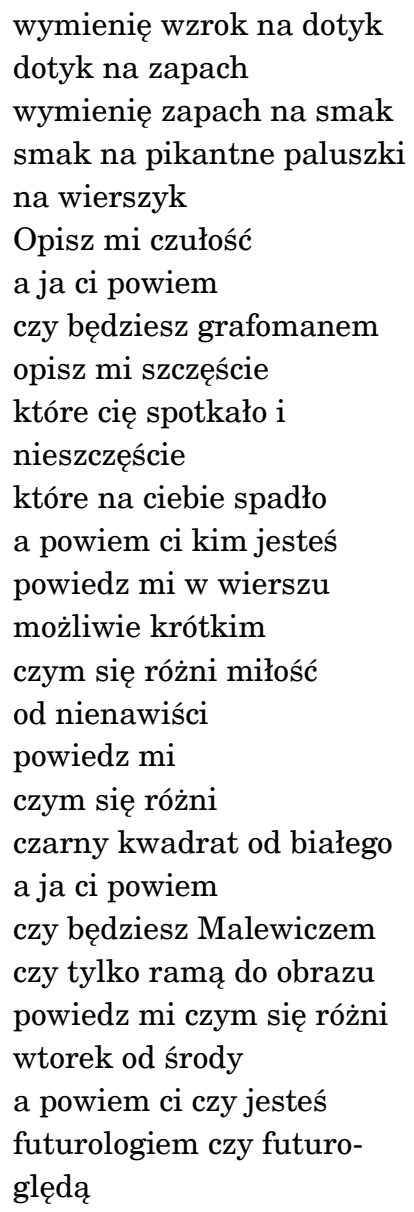

Robert Cieślak 


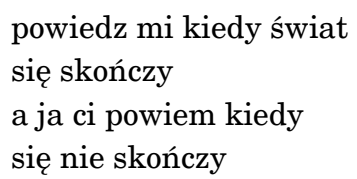

Również we wspomnianym wcześniej porządku spektakularnego istnienia znajdzie się miejsce na dialog międzytekstowy, dla którego prototekstem będzie nie tyle malarstwo Malewicza, ile łącznie traktowane założenia suprematyzmu. Spektakularność wymusza oznaczenie wartości wymiennej. Tu wskazano ją jako wartość informacji wymienianej między uczestnikami projektowanego aktu komunikacji. Przyjmując porządek analizy wynikający z założeń poetyki oglądu, należałoby przyjąć, że suprematystyczna redukcja przedstawieniowości stanowi tu nie tylko kontekst, ale także zasadę wewnątrzpodmiotowego, opozycyjnie konstruowanego procesu wymiany. Stanowi zasadę konstrukcyjną wiersza. Nie jest przygodna, nie jest przypadkowa, jest modelująca i jako taka ma przekonywać, że mediatyzowana w porządku komunikacji masowej wymiana nie jest ekwiwalentna, że zakłada swoistą jedność przedstawieniową. W świetle takich ustaleń odpowiedź na pytanie, czy możliwa jest wymiana, czy można skutecznie zrezygnować ze wzroku na rzecz dotyku, musi być negatywna.

Niech te rozważania zakończy anegdota.

Rok 2006. Wiedeń. Slawiści europejscy organizują konferencję poświęconą twórczości poety. Pretekstem jest 85. rocznica urodzin Tadeusza Różewicza. Jubilat osobiście przysłuchuje się wynikom badań i interpretacjom jego twórczości. Tuż przed rozpoczęciem obrad poeta zagadnie mnie:

- Pan tak wciąż o tym wzorku u mnie, a ja właśnie piszę wiersz o dotyku...

Po chwili ciszy, nie dostrzegając zdziwienia, jakie malować się musiało na mojej twarzy, poeta kontynuuje:

- ... tak, o dotyku... opisuję jak dotykam wzrokiem przedmiotu...

- Czyli jednak to wiersz o widzeniu - replikuję nazbyt może pospiesznie. Poeta odwraca wzrok, urywa rzecz. Konferencja się rozpoczyna.

\section{Wnioski}

W odniesieniu do twórczości Tadeusza Różewicza opisanie doświadczenia wzrokowego jest wyjaśnianiem istoty poezji i źródeł poetyckości, niezbędnym w definiowaniu poetyki oglądu. 
Poezja Różewicza nie tyle udziela obrazowi (obrazom) języka (jako semiotyka sztuki), ile jest dociekaniem poznawczym, nieustannie podejmowaną twórczą próbą odpowiedzi na pytanie, jak poznać widziane (obraz) i wyrazić w języku. W efekcie zatem - w tej perspektywie - poezja jest poznaniem, jest także filozofią sztuki.

Mimo iż prosta wymiana wzroku na dotyk nie jest możliwa, to jednak „dotykanie wzrokiem”, interpretowane $\mathrm{w}$ zgodzie $\mathrm{z}$ zasadami redukcji fenomenologicznej, byłoby sposobem opisu techniki poznawania poza dyskursem pojęciowym, poświadczałoby więc możliwość uprzedniości logosu predyskursywnego wobec logosu pojęciowego. Zmysłowe doświadczanie obrazu, poprzedzające akt językowej konkretyzacji jest więc w dalszym ciągu przykładem na realizację zasady „przemyśliwania obrazów”, w zgodzie z którą powinna być komponowana poezja, o ile chce być stosownym świadectwem poznania rzecz-y-wistości. 